\title{
Uji Efek Pelindung Hati Ekstrak Air Tanaman Kulit Lawang, Cinnamomum Cullilaban (Lauraceae), melalui Pemeriksaan MDA dan SOD Plasma Sel Darah Tikus
}

\author{
Arif Soeksmanto \\ Laboratorium Biofarmaka, Pusat Penelitian Bioteknologi LIPI, \\ Jalan Raya Bogor Km. 46, Cibinong 16911 \\ Diterima 11-12-2009 Disetujui 30-08-2010
}

\begin{abstract}
Industrial growth, pollution, and the change of life style cause environmental degradation. This condition enhances the occurrence of degenerative diseases that more difficult to conquer than infective diseases. This promotes the use of herbs in America up to $385 \%$ in period 1990-1997, wasting 4-12 billion dollar each year. World Health Organization (WHO) estimates approximately 4 billion or $80 \%$ of world citizens use herbs for their health care. Kulit lawang plants are medicinal plants grown endemically in Papua and Maluku regions. The existence of the plants in Maluku islands is considered as endangered species. Information on the plants in scientific publication is relatively limited. meanwhile Cinnamomum sp. is known having high antioxidant compound. This research aimed to find out hepatoprotector effect of kulit lawang water extract through observation of MDA and SOD of venous blood of rat intoxicated with $\mathrm{CCl}_{4}$. Dosage used was based on result of effective dosage test which showed that water extract of kulit lawang plant of $20 \mathrm{mg} / \mathrm{kg}$ bw as highest dosage that did not harm animal health. Result of hepatoprotector effect test showed that MDA and SOD of control were $230.12 \mathrm{U} / \mathrm{ml}$ and $1243.00 \mathrm{pmol} / \mathrm{ml}$, whereas water extract of kulit lawang was $414.45 \mathrm{U} / \mathrm{ml}$ and $793.00 \mathrm{\rho mol} / \mathrm{ml}$, á-tocopherol $416.42 \mathrm{U} / \mathrm{ml}$ and $782.33 \mathrm{\rho mol} / \mathrm{ml}$, and curcumin $426.07 \mathrm{U} / \mathrm{ml}$ and $734.00 \mathrm{\rho mol} / \mathrm{ml}$. This showed that water extract of kulit lawang plant has antioxidant properties and potential as hepatoprotector of oxidative damage.
\end{abstract}

Keywords : Blood, Cinnamomum cullilaban, Hepatoprotector, Kulit Lawang, MDA, Rat, SOD, water extract

\section{PENDAHULUAN}

Kemajuan teknologi tidak terlepas dari peningkatan jumlah penduduk, pertumbuhan industri, polusi dan perubahan gaya hidup yang berakibat pada memburuknya kondisi lingkungan. Keadaan ini, memicu munculnya jenis penyakit degeneratif yang justru lebih sulit diatasi dibanding penyakit infektif. Bahkan penyakit degeneratif (seperti kanker, hepatitis, jantung, artritis, diabetes dsb) telah banyak merenggut nyawa manusia.

Belakangan diketahui bahwa kerusakan lingkungan berhubungan dengan perubahan iklim global yang mengancam tenggelamnya daratan, sampai timbulnya penyakit baru yang sulit disembuhkan. Hal tersebut mendorong munculnya istilah back to nature yang bukan saja menganjurkan masyarakat untuk peduli pada lingkungan, tetapi juga mengkonsumsi herbal.

Di Amerika pada periode 1990-1997 penggunaan herbal meningkat hingga 385\% dengan menghabiskan 4-12 milyar dolar setiap tahunnya (Eisenberg et al., 1993).

Telp: 081316369336

Email: a_soeksmanto@yahoo.com
Bahkan WHO memperkirakan ada sekitar 4 milyar atau $80 \%$ penduduk dunia menggunakan herbal untuk perawatan kesehatannya, sedangkan di Indonesia sendiri, penggobatan tradisional herbal sudah dikenal sejak ratusan tahun lalu dan setiap tahunnya selalu bermunculan produk-produk baru di pasaran. Keadaan ini menunjukkan bahwa pengadaan produk-produk herbal masih sangat dibutuhkan baik di lingkungan masyarakat Indonesia maupun masyarakat dunia.

Penelitian ini bertujuan mengungkap potensi tanaman kulit lawang sumber antioksidan sebagai guna memenuhi kebutuhan masyarakat akan obat herbal. Tanaman kulit lawang merupakan tanaman obat yang tumbuh endemik di daerah Papua dan Maluku. Tanaman ini beraroma seperti cengkeh dan digunakan sebagai penyedap, obat gosok, kulit maupun kolera. Meskipun demikian keberadaan tanaman kulit lawang di Kepulauan Maluku pada saat ini sudah sangat terancam. Sementara publikasi ilmiahnya masih sangat jarang dan umumnya hanya berkisar pada kandungan senyawa kimia minyak atsirinya saja. 
Menurut Shan et al., (2005) marga dari tanaman ini mengandung senyawa antioksidan tinggi dan minyak atsirinya memiliki efek antimikroba (López et al., 2005).

Penelitian epidemiologis membuktikan bahwa stress oksidatif selalu berhubungan dengan patogenesis dan perkembangan berbagai penyakit kronis (Sunita et al., 2000). Oleh karena itu pengembangan potensi antihepatotoksik dan antioksidan menjadi penting, khususnya penggunaan bahan alami dalam mengatasi penyakit hati (Hussein et al., 2007).

Penelitian ini menggunakan $\mathrm{CCl}_{4}$ yang umum digunakan dalam penelitian hepatotoksisitas, meskipun mekanisme aksi $\mathrm{CCl}_{4}$ rumit, melibatkan banyak faktor dan belum sepenuhnya dapat dimengerti (Sisodia \& Bhatnagar, 2009). Prinsipnya $\mathrm{CCl}_{4}$ masuk ke dalam tubuh, tertimbun di dalam sel-sel parenkimal hati dan dibiotransformasi sistem sitokrom $\mathrm{P}_{450}$, sehingga menghasilkan radikal triklorometil $\left(\mathrm{CCl}_{3}\right)$. Radikal ini, kemudian dikonversi kembali menjadi radikal peroksi $\left(\mathrm{CCl}_{3} \mathrm{O}_{2}\right)$ yang lebih toksik (Recknagel, 1983).

Superoksida Dismutase (SOD) adalah sistem pertahanan tubuh yang berfungsi mengubah radikal superoksida menjadi $\mathrm{H}_{2} \mathrm{O}_{2}$ yang kurang toksik, Sedangkan Malondialdehid (MDA) adalah produk akhir dari proses peroksidasi lemak yang disebabkan oleh stres oksidatif. Menurut Tokyay et al., (1999) kadar MDA dapat digunakan untuk mendeterminasi awal terjadinya stress oksidatif hati.

Mengingat keberadaan tanaman kulit lawang yang sangat terancam, kebutuhan masyarakat akan obat herbal serta tingginya kandungan senyawa antioksidan marga Cinnamomum sp. maka diharapkan hasil penelitian ini dapat menjadi masukan yang berguna dalam melengkapi fitofarmaka Indonesia.

\section{BAHAN DAN METODE}

Material tanaman kulit lawang dikoleksi dari daerah Seram Bagian Barat, Propinsi Maluku. Sampel material tanaman diindentifikasikan di Herbarium Bogoriense, Bidang Botani Pusat Penelitin Biologi-LIPI untuk memastikan jenis tumbuhan yang dimaksud. Setelah dipastikan, maka dilakukan pemotongan dan pengeringan untuk persiapan ekstraksi.

Pencarian dosis efektif ekstrak air tanaman kulit lawang dilakukan pada tikus Sprague Dawley jantan dengan dosis $0,5,10,15,20$ dan $30 \mathrm{mg} / \mathrm{kg}$ bb secara intragastrik yang diamati selama 7 hari. Pengunjian efek pelindung hati dengan tikus yang sama, tetapi perlakuannya adalah pelarut (kontrol normal), kurkumin (kontrol positif 1), á-tokoferol (kontrol positif 2) dan ekstrak air tanaman kulit lawang. Pemberian bahanbahan tersebut dilakukan selama 7 hari, kemudian tikus diintoksikasi dengan $\mathrm{CCl}_{4}$ dan diamati hingga 14 hari setelah pemberian $\mathrm{CCl}_{4}$.

Data kadar MDA dan SOD diambil pada hari ke-7, 3, dan 1 sebelum intoksikasi $\mathrm{CCl}_{4}$ dan hari 1, 2, 3, 5, 7 dan 14 setelah intoksikasi. Penelitian ini menggunakan 5 ulangan dengan sampel darah dari vena jungularis. Sampel darah tersebut selanjutnya disentrifugasi untuk memisahkan plasma (MDA) dan sel darah merah (SOD) serta diamati menggunakan alat spektrofotometer.

\section{HASIL DAN PEMBAHASAN}

Berdasarkan ekstraksi tanaman kulit lawang yang dilakukan, diketahui bahwa $250 \mathrm{~g}$ serbuk yang direfluks 5 kali dengan 4 liter aquades, menghasilkan 73,67 g ekstrak air, Pencarian dosis efektif, didapat dosis $20 \mathrm{mg} / \mathrm{kg}$ bb sebagai dosis tertinggi yang tidak mengganggu kesehatan hewan. Hasil pemeriksaan kadar MDA dan SOD selama penelitian berlangsung, disajikan, pada Tabel 1 dan 2.

Berdasarkan hasil penelitian, diketahui bahwa pemberian ekstrak air tanaman kulit lawang tidak menyebabkan kerusakan pada sel-sel hati. Hal tersebut juga terlihat dari hasil uji statistik kadar MDA dan SOD seluruh perlakuan yang tidak berbeda. Hal ini menunjukkan bahwa pemberian dosis ekstrak $20 \mathrm{mg} / \mathrm{kg}$ bb tidak toksik bagi hewan percobaan. Intoksikasi $\mathrm{CCl}_{4}$ memberikan pengaruh yang nyata pada gambaran histologi, berupa radang (terdapat banyak sel-sel makrofag) yang mengawali terjadinya nekrosis

Tabel 1. Hasil pengamatan histologi, kadar MDA dan SOD tikus sebelum diintoksikasi $\mathrm{CCl}_{4}$ pada uji efek pelindung hati ekstrak air

\begin{tabular}{|c|c|c|c|c|c|c|c|c|}
\hline \multirow{2}{*}{$\begin{array}{c}\text { Hari } \\
\text { ke }\end{array}$} & \multicolumn{2}{|c|}{ Kontrol } & \multicolumn{2}{|c|}{ Kurkumin } & \multicolumn{2}{|c|}{$\alpha$-tocopherol } & \multicolumn{2}{|c|}{ Kulit lawang } \\
\hline & MDA & SOD & MDA & SOD & MDA & SOD & MDA & SOD \\
\hline-7 & 130 & 432 & 130 & 432 & 130 & 432 & 130 & 432 \\
\hline-3 & 140 & 482 & 138 & 418 & 138 & 428 & 138 & 418 \\
\hline-1 & 130 & 218 & 140 & 197 & 143 & 195 & 133 & 202 \\
\hline$\Sigma$ & 400 & 1132 & 408 & 1047 & 410 & 1055 & 401 & 1052 \\
\hline$x$ & 133 & 377 & 136 & 349 & 137 & 352 & 134 & 351 \\
\hline
\end{tabular}


Tabel 2. Hasil pengamatan histologi, kadar MDA dan SOD tikus setelah diintoksikasi $\mathrm{CCl}_{4}$ pada uji efek pelindung hati ekstrak air tanaman kulit lawang

\begin{tabular}{ccccccccc}
\multicolumn{2}{c}{ Kari } & \multicolumn{2}{c}{ Kontrol CCl $_{4}$} & \multicolumn{2}{c}{ Kurkumin } & \multicolumn{2}{c}{ a-tocopherol } & \multicolumn{2}{c}{ Kulit Lawang } \\
\hline He & MDA & SOD & MDA & SOD & MDA & SOD & MDA & SOD \\
1 & 237 & 122 & 210 & 183 & 387 & 142 & 243 & 183 \\
2 & 1505 & 258 & 907 & 335 & 907 & 395 & 1128 & 312 \\
3 & 1718 & 243 & 1704 & 348 & 1775 & 397 & 1746 & 387 \\
5 & 1613 & 249 & 763 & 475 & 816 & 452 & 924 & 445 \\
7 & 1477 & 253 & 563 & 557 & 587 & 525 & 536 & 530 \\
14 & 908 & 255 & 276 & 658 & 222 & 588 & 181 & 630 \\
$\Sigma$ & 7458 & 1381 & 4404 & 2556 & 4694 & 2499 & 4758 & 2487 \\
$\mathrm{X}$ & 1243 & 230 & 344 & 426 & 782 & 416 & 793 & 414 \\
\hline
\end{tabular}

sel hati. Menurut Guyton dan Hall (2000) stadium awal peradangan ditandai dengan munculnya sel-sel neutrofil pada daerah yang terpapar toksikan. Penjelasan terjadinya infiltrasi sel-sel radang ke dalam hati diawali dengan masuknya toksikan ke dalam hati yang menyebabkan peningkatkan aktivitas sel (khususnya sel-sel sinusoid endotelial dan hepatosit) dan antigen leukosit 1 (LFA-1) disekitar dinding pembuluh. Kemudian toksikan dan LFA-1 tertimbun di daerah nekrosis, sehingga meningkatkan aktivitas sel-sel radang dan menimbulkan hepatotoksisitas (Neubauer, 1998).

Kerusakan sel hati akibat intoksikasi $\mathrm{CCl}_{4}$ berasal dari hasil metabolisme $\mathrm{CCl}_{4}$ oleh sistem sitokrom $\mathrm{P}_{450}$, yang menghasilkan radikal trikhlorometil. Menurut Hodgson dan Levi, (2000), aktivasi ikatan kovalen radikal terhadap makromolekul yang tidak tercegah oleh pertahanan antioksidan tubuh akan memicu terjadinya kerusakan peroksidatif pada lemak membran retikulum endoplasmik. Hal ini dapat terjadi karena membran retikulum endoplasmik kaya akan asam-asam lemak tak jenuh (Johnson \& Bhutani, 2002). Oleh karena itu kadar SOD dan antioksidan tubuh lainnya akan menurun saat sel hati nekrosis. Kerusakan peroksidatif ini, kemudian menyebabkan membran sel menjadi rentan, mudah pecah dan dapat mengakibatkan kematian sel (Lu, 1995), sehingga menyebabkan terjadinya hepatotoksisitas $\mathrm{CCl}_{4}$ (Cotran et al., 1994).

Sebaliknya saat sel hati nekrosis kadar MDA justru akan meningkat, karena MDA merupakan produk dekomposisi dari proses peroksidasi lemak yang disebabkan stres oksidatif. Menurut Mitra et al., (1998) konsentrasi MDA dalam sirkulasi darah dapat digunakan sebagai penanda kuantitatif akan luas dan tipe kerusakan sel hati (Mitra et al., 1998). Peningkatan kadar MDA ini tampak jelas pada hari ke-2 setelah intoksikasi $\mathrm{CCl}_{4}$.

Pada hari ke 5 setelah diintoksikasi $\mathrm{CCl}_{4}$, tikus yang diberi pengobatan tampak telah mengalami regenerasi. Hal ini sesuai dengan hasil pemeriksaan MDA dan SOD yang sangat berbeda antara hari ke 3 dengan hari ke 5, sementara kontrol $\mathrm{CCl}_{4}$ (tikus tanpa pengobatan), baru mencapai regenerasi pada hari ke 14. Menurut Huxtable, (1988), kerusakan berat dapat menghambat proses regenerasi dan meninggalkan bekas luka halus, meskipun hati telah normal kembali. Pada kasus keracunan berat, kegagalan fungsi hati dapat menyebabkan kematian dalam waktu 12-24 jam (Huxtable, 1988).

Pada hari ke-7 setelah intoksikasi, tampak selsel hati tikus yang diobati telah kembali normal, sedangkan pada kontrol $\mathrm{CCl}_{4}$ masih memperlihatkan tanda-tanda pemulihan berupa inti sel yang tidak seragam (pleomorfik). Penurunan kadar MDA dan meningkatnya kadar SOD yang tertinggi terjadi antara hari ke-5 dan ke-7, diduga saat itu antioksidan tubuh mulai mampu mengatasi gangguan oksidatif toksisitasi $\mathrm{CCl}_{4}$.

Berdasarkan hasil uji statistik kadar MDA dan SOD (hari ke 5 dan ke-7 setelah intoksikasi $\mathrm{CCl}_{4}$ ), diketahui tidak ada perbedaan diantara perlakuan obat yang diberikan. Meskipun demikian seluruh perlakuan obat berbeda nyata dengan kontrol $\mathrm{CCl}_{4}$. Hasil ini, membuktikan bahwa ekstrak air tanaman kulit lawang memiliki kemampuan melindungi sel-sel hati dari kerusakan oksidatif yang setara dengan á-tokoferol dan kurkumin.

\section{KESIMPULAN}

Pemberian $20 \mathrm{mg} / \mathrm{kg}$ bb ekstrak tanaman kulit lawang, tidak toksik bagi hewan percobaan, bahkan berpotensi menghambat kerusakan peroksidatif pada tikus yang diintoksikasi $\mathrm{CCl}_{4}$. Daya hambat kerusakan peroksidatif ekstrak tanaman kulit lawang, setara dengan á-tokoferol dan kurkumin yang diketahui mengandung antioksidan tinggi. 


\section{UCAPAN TERIMA KASIH}

Penulis mengucapkan terima kasih kepada penyelenggara "Kegiatan Program Insentif bagi Peneliti dan Perekayasa Lembaga IImu Pengetahuan Indonesia" yang telah mendanai kegiatan ini. Ucapan terima kasih juga penulis sampaikan kepada saudara Bustanussalam atas bantuan teknisnya dalam penyediaan ekstrak kulit lawang yang dibutuhkan.

\section{DAFTAR PUSTAKA}

Cotran, R.S., Kumar, V. \& Collins, T. 1999. Robbins Pathologic Basis of disease, $6^{\text {th }}$ ed. Philadelphia : WB Saunders Co.

Eisenberg, D.M., Kessler, R.C., Foster, C., Norlock, F.E., Calkins, D.R. \& Delbanco, T.L. (1993). Unconventional medicine in the United states. $N$ England Journal Med 328: 246-252.

Guyton, A.C. \& Hall, J.E. 2000. A textbook of Medical Physiology. $10^{\text {th }}$ Edition Saunders WB, Company Philadelphia.

Hodgson, E. \& Levi, P.E. 2000. A Textbook of Modern Toxicology. 2nd edition. McGraw-Hill.

Huxley, C.R. 1993. The tuberosus epiphytes of the rubiaceae 6: A taxonomic history of the hydnophytinae. Blumea 37: 335340.

Johnson, L. H. \& Bhutani, V. K. 2002. System based approach to management of neonatal jaundice and prevention of kernicterus. Journal Pediatric 140: 396-403.
López, P., Sánchez, C., Batlle, R. \& Nerín, C. 2005. Solid- and vapor-phase antimicrobial activities of six essential oils: susceptibility of selected foodborne bacterial and fungal strains. Journal Agric. Food Chem 53(17): 6939-46.

Lu, Frank C. 1995. Toksikologi Dasar Asas Organ Sasaran dan Penilaian Resiko. Penerjemah : Edi Nugroho. Penerbit Ul. Jakarta.

Mitra, S.K., Venkataraganna, M.V., Sundaran, R. \& Gopumadhavan, S. (1998). Protective effect of HD-03, a herbal formulation against various hepatotoxic agents in rats. Journal Ethno. Pharmacol 63: 181-6

Neubauer, K. 1998. Carbon tetrachloride induced liver injury. Lab. Invest. 78(2): 185-194

Recknagel, R. O. 1983. A new direction in the study of carbon tetrachloride hepatotoxicity, Life Sci 33: 401-408

Shan, B., Cai, Y.Z., Sun, M. \& Corke, H. 2005. Antioxidant capacity of 26 extracts and characterization of their phenolic constituents. Journal Agric. Food Chem 53(20): 7749-59.

Sisodia, S.S. \& Bhatnagar, M. 2009. Hepatoprotective activity of Eugenia jambolana Lam. in carbon tetrachloride treated rats. Indian. Journal Pharmacol 41: 23-27.

Sunita,T., Vupta, V. \& Sandeep, B. 2000. Comparative study of antioxidant potential of tea with and without additivies, Indian. Journal Physiol. Pharmacol 44: 215-219.

Tokyay, R., Kaya, E., Gur, E.S., Tuncel, P., Ozbek, R. \& Oztuk, E. 1999. Prostaglandin Synthetase inhibition reduces peritonitis induced early liver oxidant stress. Surg. Today 29(1): $42-46$. 